\title{
PENGEMBANGAN PERANGKAT PEMBELAJARAN MODEL GROUP INVESTIGATION DENGAN ADVANCE ORGANIZER UNTUK MENINGKATKAN HASIL BELAJAR DAN KETERAMPILAN PEMECAHAN MASALAH PADA SISWA SMP
}

Oleh

Yeni Puji Astuti

STKIP PGRI Sumenep

Email: yeni_puji.062003@yahoo.co.id

\begin{abstract}
This research aims to develop a learning material of group investigation model with advance organizer to improve learning output and student's problem solving skills in SMPN 1 Tanjungbumi. This study would be expected to be applied using the several assessing of instruments. The experiment design of the material resources used one group pretest-posttest design. The assessing of instruments consist of lesson plan, BAS, worksheet, observing activity, test (product, process, and psychomotor), and questionnaire.

The validity result showed that lesson plan, BAS, and LKS had in feasible category, LP product and LP process had in feasible category. The assessment of BAS and LKS showed that BAS and LKS had in understandable material by students. Learning feasibility of group investigation model with advance organizer is in excellent category. Reliability of students' activity observation from the lesson plan with the percentage $92,32 \%$. The completeness of product's indicator with the percentage $83,33 \%$, and the completeness of process' indicator (problem solving skills) with the percentage $73,33 \%$. The completeness of the individual output product with the percentage $93,33 \%$, the completeness of the individual output process (problem solving skills) with the percentage $93,33 \%$, the completeness of the individual output psikomotor with the percentage $100 \%$, and the completeness of the individual output afektif with the percentage 100\%. Group investigation model with advance organizer got positive respond from the students. The difficulties found during this study was group investigation model with advance organizer was a new thing for the students so the teacher should give information about group investigation model with advance organizer for the students.
\end{abstract}

\section{Keywords: Group Investigation, Output \& Problem Solving}

\section{PENDAHULUAN}

Perkembangan IPTEK tidak dapat lepas dari peranan Ilmu Pengetahuan Alam (IPA). IPA berkaitan dengan cara mencari tahu tentang alam secara sistematis, sehingga IPA bukan hanya penguasaan kumpulan pengetahuan yang berupa fakta-fakta, konsep-konsep, atau prinsip-prinsip saja tetapi juga merupakan suatu proses penemuan. Pendidikan IPA diharapkan dapat menjadi wahana bagi peserta didik untuk mempelajari diri sendiri dan alam sekitar, serta prospek pengembangan lebih lanjut dalam menerapkannya di dalam kehidupan seharihari.
Dikaitkan dengan kehidupan sehari-hari, pembelajaran IPA berhubungan sekali dengan kehidupan nyata. Namun, siswa kebanyakan hanya menghafal konsep materi dan kurang mampu menggunakan konsep materi tersebut dalam masalah-masalah kehidupan nyata. Pemahaman konsep sangat penting dalam proses pembelajaran agar siswa mempunyai kemampuan memecahkan masalah.

Berdasarkan Permendiknas No. 22 tahun 2006, tujuan pendidikan dalam mata pelajaran IPA di Sekolah Menengah Pertama, peserta didik diharapkan memiliki kemampuan melakukan inkuiri ilmiah untuk menumbuhkan 
kemampuan berfikir, bersikap dan bertindak ilmiah, maka dapat diyakini bahwa lulusan Sekolah Menengah Pertama dengan daya nalarnya mampu memecahkan masalah yang dihadapi dalam kehidupan sehari-hari, memiliki sikap ilmiah, mampu menerapkan konsep dan prinsip-prinsip IPA serta mampu menggunakan teknologi sederhana.

Kesuksesan seorang siswa tergantung pada kecakapan abad 21, sehingga siswa harus belajar untuk memilikinya. Keterampilan abad 21 merupakan kemampuan dan perilaku yang harus dimiliki oleh generasi muda agar menjadi kompetitif dalam ekonomi global berbasis pengetahuan. Partnership for $21^{\text {st }}$ Century Skills mengidentifikasi kecakapan abad 21 meliputi : berpikir kritis, pemecahan masalah, komunikasi dan kolaborasi (Trisdiono \& Muda, 2013).

Kemampuan pemecahan masalah menjadi salah satu tujuan yang diharapan untuk dimiliki oleh siswa dalam proses pembelajaran dan dalam kehidupan sehari-hari. Kemampuan ini tidak hanya ditunjang dengan fasilitas yang baik tetapi juga harus didukung oleh kemampuan guru untuk mengelola pembelajaran dengan baik.

Salah satu masalah dalam pembelajaran adalah masih rendahnya daya serap peserta didik. Pencapaian kemampuan sains siswa di Indonesia dapat dilihat berdasarkan hasil penilaian TIMSS. Menurut (Efendi, 2010) menyatakan bahwa rata-rata skor siswa Indonesia pada TIMSS tahun 1999, 2003, dan 2007 secara berturutan adalah 435, 420, dan 433. Dengan skor tersebut siswa Indonesia menempati peringkat 32 dari 38 negara (tahun 1999), peringkat 37 dari 46 negara (tahun 2003), dan peringkat 35 dari 49 negara (tahun 2007). Hasil survei TIMSS tahun 2011 (Provasnik, et al., 2012), menunjukkan bahwa rata-rata skor pretsasi sains adalah sebesar 406, yang mengalami penurunan dari tahun 2007. Dari hasil survei TIMSS, rata-rata skor prestasi sains siswa Indonesia di bawah skor rata-rata yaitu 500, dan hanya mencapai Low International Benchmark.
Jika dikualifikasi, skor rata-rata Indonesia tergolong pada tingkat yang rendah. Komposisi soal-soal TIMSS yang diujikan didominasi oleh soal-soal pemecahan masalah, dan soal-soal pemecahan masalah inilah yang menjadi titik lemah siswa Indonesia yang menyebabkan skor yang diperoleh rendah. Kemampuan pemecahan masalah merupakan bagian dari kemampuan berfikir tingkat tinggi. Berdasarkan hal tersebut, dengan mengacu kepada hasil analisis TIMSS, kemampuan pemecahan masalah siswa SMP di Indonesia masih sangat rendah, jauh berada di bawah skor rata-rata internasional.

Menurut TSOI, et. al., (2004), belajar harus dipersonalisasi, diatur dalam konteks nyata dan berorientasi pada pemecahan masalah. Keterampilan pemecahan masalah dapat dipandang sebagai proses siswa menemukan kombinasi aturan-aturan yang dipelajarinya lebih dahulu yang digunakan untuk menyelesaikan masalah yang baru. Siswa yang terlatih dengan pemecahan masalah akan terampil menyeleksi informasi yang relevan, kemudian menganalisisnya dan meneliti hasilnya. Keterampilan itu akan menimbulkan kepuasan intelektual dalam diri siswa, meningkatkan potensi intelektual, dan melatih siswa bagaimana melakukan penelusuran melalui penemuan.

Salah satu masalah pokok dalam pembelajaran pada pendidikan formal dewasa ini adalah masih rendahnya daya serap peserta didik terhadap materi pelajaran. Prestasi ini merupakan hasil kondisi pembelajaran yang masih bersifat konvensional dan tidak menyentuh ranah dimensi peserta didik itu sendiri, yaitu bagaimana sebenarnya belajar itu sendiri. Dalam arti yang substansial, bahwa proses pembelajaran hingga dewasa ini masih memberikan dominasi guru dan tidak memberikan akses bagi anak didik untuk berkembang secara mandiri melalui penemuan dan proses berfikirnya (Suhendri dan Sahyar, 2012).

Hasil studi pendahuluan di SMP Negeri 1 Tanjungbumi, hasil belajar siswa masih 
tegolong rendah dengan standar KKM 65, hasil belajar yang dicapai siswa rata-tara 68. Secara klasikal hasil belajar dikategorikan tuntas, namun secara individu hasil belajar siswa masih rendah. Fakta-fakta dari hasil studi pendahuluan tentang proses pembelajaran yaitu: 1) metode pembelajaran IPA yang digunakan guru kurang inovatif, guru lebih sering menggunakan metode ceramah, demonstrasi, tanya jawab, tugas rutin, dan mengerjakan latihan soal; 2) media pembelajaran IPA yang digunakan guru kurang bervariasi; 3) laboratorium IPA kurang digunakan secara optimal.

Salah satu usaha untuk meningkatkan keberhasilan proses belajar mengajar adalah dengan menerapkan strategi atau pendekatan pembelajaran yang efektif, efisien, dan menyenangkan guna mencapai tujuan pembelajaran yang diinginkan. Tujuan pembelajaran secara efektif dapat tercapai apabila dalam proses belajar mengajar siswa mendapat pengetahuan yang bermakna, dan terjadinya perubahan tingkah laku yang baik, hal ini dapat dicapai dengan partisipasi aktif siswa dalam pembelajaran (Karli \& Sriyuliariatiningsih, 2004:75).

Pembenahan dalam proses belajar mengajar IPA harus dilakukan untuk menentukan keberhasilan siswa dalam mencapai kualitas pembelajaran IPA sesuai dengan tujuan pendidikan. Dengan demikian, seorang guru harus berupaya menciptakan lingkungan belajar yang mendorong siswa belajar atau memberi kesempatan kepada siswa untuk berperan aktif mengkonstruksi konsep-konsep yang dipelajarinya dengan menerapkan berbagai pendekatan, strategi, model, dan metode pembelajaran yang dapat meningkatkan mutu pembelajaran.

Beberapa tipe model pembelajaran kooperatif antara lain; (1) Student Team Achievment Division (STAD); (2) TAI; (3) Jigsaw. Selain itu terdapat tipe model GI (Group Investigation). Group investigation merupakan salah satu bentuk model pembelajaran kooperatif yang menekankan pada partisipasi dan aktivitas siswa untuk mencari sendiri materi (informasi) pelajaran yang akan dipelajari melalui bahan-bahan yang tersedia. Siswa dilibatkan sejak perencanaan, baik dalam menentukan topik maupun cara untuk mempelajarinya melalui investigasi. Model group investigation memiliki kelebihan diantaranya adalah dapat melatih siswa untuk menumbuhkan kemampuan berfikir mandiri melalui investigasi, serta efektif dalam membentuk siswa untuk bekerjasama dalam kelompok dengan latar belakang berbeda dan meningkatkan aktivitas belajar siswa (Mcklar, 2008).

Kelebihan model Group Investigation tersebut juga dapat meningkatkan hasil belajar siswa dan keterampilan pemecahan masalah. Salah satu konsep utama dalam model Group Investigation yaitu penelitian (inqury), proses dimana siswa dirangsang dengan cara menghadapkannya pada masalah, sehingga penggunaan model Group Investigation dapat melatihkan keterampilan pemecahan masalah. Menurut Dewi, dkk (2012), bahwa model pembelajaran Group Investigation cocok diterapkan pada materi yang membutuhkan pengamatan secara langsung sehingga dapat mempermudah siswa menerima materi.

Pada tahap investigasi kelompok, siswa dapat saling bertukar pendapat dan berdiskusi antar anggota kelompok, dimana kegiatan tersebut dapat merangsang siswa untuk mengkaitkan informasi-informasi sehingga mampu menciptakan solusi baru untuk suatu masalah. Keterampilan pemecahan masalah bertujuan agar siswa peka terhadap masalah yang ada di lingkungan. Namun, dari kelebihan model Group Investigation juga memiliki kekurangan yaitu dalam pengorganisasian tahap awal pembelajaran.

Dengan mengkaji langkah-langkah model Group Investigation dalam Slavin (1995), pada tahap awal model Group Investigation hanya mengidentifikasi topik dan mengorganisasikan siswa dalam kelompok tetapi siswa tidak diberi suatu pengarahan untuk mengingatkan kembali pengetahuan atau pengalaman siswa yang relevan. Advance Organizer merupakan alternatif solusi untuk mengatasi kekurangan dalam 
pengorganisasian tahap awal pembelajaran. Penggunaan Advance Organizer yang merupakan suatu alat pengajaran yang direkomendasikan oleh Ausubel untuk mengaitkan bahan-bahan pembelajaran baru dengan pengetahuan awal yang diharapkan dalam struktur kognitif siswa akan tercipta suatu model kerangka berpikir tentang suatu topik pelajaran yang berguna untuk memulai suatu pelajaran baru, sehingga belajar bermakna dapat berlangsung dalam diri siswa.

Banyak siswa dalam pembelajaran yang tidak mempunyai konsep-konsep yang relevan dalam struktur kognitifnya, sehingga siswa kesulitan memahami konsep-konsep baru yang diajarkan guru, yang pada akhirnya konsep-konsep baru itu diterima secara hafalan. Tugas guru sebagai perancang pembelajaran harus dapat menolong para siswa untuk menemukan konsep-konsep yang relevan dan menggunakan konsep-konsep tersebut dalam struktur kognitif siswa untuk mengasimilasikan konsep baru yang akan diajarkan oleh guru sehingga efek belajar bermakna dapat berlangsung oleh siswa itu sendiri.

Alternatif solusi yang mampu meningkatkan hasil belajar dan keterampilan pemecahan masalah dengan menyusun perangkat pembelajaran model Group Investigation dengan Advance Organizer yang belum tersedia, sehingga perlu adanya perangkat pembelajaran model Group Investigation dengan Advance Organizer yang dikembangkan dengan tujuan untuk menunjang dan mendukung proses pembelajaran.

Berdasarkan latar belakang masalah di atas, maka dirumuskan masalah secara umum: "Bagaimana kelayakan dan hasil uji coba Pengembangan Perangkat Pembelajaran Model Group Investigation dengan Advance Organizer untuk Meningkatkan Hasil Belajar dan Keterampilan Pemecahan Masalah pada Siswa SMP?" Untuk menjawab rumusan masalah umum di atas maka dirumuskan masalah penelitian secara khusus sebagai berikut: 1) Bagaimana kelayakan perangkat pembelajaran Model Group Investigation dengan Advance Organizer yang dikembangkan?, dan 2) Bagaimana hasil uji coba perangkat pembelajaran Model Group Investigation dengan Advance Organizer yang dikembangkan?

\section{METODE PENELITIAN}

Penelitian ini termasuk penelitian dan pengembangan (research and development) karena mengembangkan pembelajaran Model Group Investigation dengan Advance Organizer untuk meningkatkan hasil belajar dan keterampilan pemecahan masalah siswa SMPN 1 Tanjungbumi dan memvalidasi produk pendidikan. Perangkat yang dikembangkan adalah Rencana Pelaksanaan Pembelajaran (RPP), Buku Ajar Siswa (BAS), Lembar Kegiatan Siswa (LKS), dan Lembar Penilaian (LP). Penelitian dilaksanakan di kelas VIII SMPN 1 Tanjungbumi pada semester ganjil tahun pelajaran 2013/2014.

Subjek dalam penelitian ini adalah perangkat pembelajaran dan siswa kelas VIII SMP Negeri 1 Tanjungbumi tahun ajaran 2013/2014. Pada uji coba lapangan menggunakan 3 kelas replikasi dengan tujuan untuk menghasilkan taksiran yang lebih teliti dan memungkinkan diperolehnya suatu taksiran yang lebih baik,

Desain ujicoba perangkat pembelajaran menggunakan model One Group PretestPosttest Design. Sebelum melaksanakan pembelajaran dilaksanakan tes awal (pretest) $\mathrm{U}_{1}$, dan setelah melaksanakan pembelajaran model Group Investigation dengan Advance Organizer L dilakukan tes akhir (posttest) $\mathrm{U}_{2}$. Peneliti menggunakan tiga teknik pengumpulan data yaitu observasi, tes dan angket.

Perhitungan reliabilitas digunakan untuk mengetahui kualitas instrumen. Instrumen dikatakan baik (reliabel) jika nilai reliabilitas yang diperoleh $\geq 75 \%$ (Borich, 1994).

Gain adalah selisih antara nilai posttest dan pretest, gain menunjukkan peningkatan pemahaman atau penguasaan konsep siswa setelah pembelajaran dilakukan guru. Gain yang dinormalisasi (N-gain) dapat dihitung dengan persamaan: (Hake, 1998). 


\section{HASIL DAN PEMBAHASAN}

Penelitian ini dilaksanakan pada 75 siswa kelas VIII SMP Negeri 1 Tanjungbumi pada semester ganjil tahun pelajaran 2013/2014. Perangkat pembelajaran model group investigation dengan advance organizer dikembangkan untuk meningkatkan hasil belajar dan keterampilan pemecahan masalah pada siswa SMP, terdiri dari Rencana Pelaksanaan Pembelajaran, Buku Ajar Siswa, Lembar Kegiatan Siswa, dan Lembar Penilaian.

Hasil validasi perangkat pembelajaran model Group Investigation dengan Advance Organizer yang dikembangkan dapat kita lihat pada tabel di bawah ini.

Tabel 1. Hasil Validasi Perangkat

\begin{tabular}{|c|c|c|c|}
\hline Perangkat & $\begin{array}{c}\text { Nilai } \\
\text { rata-rata } \\
\text { validasi }\end{array}$ & Kategori & Reliabilitas \\
\hline RPP & 3,1 & Baik & $80,5 \%$ \\
\hline BAS & 3,4 & Baik & $78,43 \%$ \\
\hline LKS & 3,5 & Baik & $82,38 \%$ \\
\hline LP & 3,3 & Baik & $85,86 \%$ \\
\hline
\end{tabular}

Hasil validasi perangkat pembelajaran pada Tabel 1 menunjukkan bahwa perangkat pembelajaran yang dikembangkan dapat dikatakan reliabel, hal ini sesuai dengan pernyataan Borich (1994:385) yang menyatakan bahwa instrument dikatakan baik (reliable) jika nilai reliabilitasnya $\geq 75 \%$.

Keterlaksanan RPP terbagi atas pengamatan KBM dan suasana kelas. Pelaksanaan terdiri dari pendahuluan, kegiatan inti dan penutup. Rata-rata persentase keterlaksanaan RPP Replikasi I, II, dan III adalah $81,80 \%, 81,36 \%$, dan $81,36 \%$ dengan reliabilitas antara dua pengamat mencapai $94,24 \%, 95,04 \%$, dan $95,04 \%$. Rata-rata skor yang diperoleh menunjukkan bahwa secara keseluruhan RPP terlaksana dengan sangat baik.

Aspek pada keterlaksanaan RPP mendapat skor yang relatif tinggi dengan kategori sangat baik. Hal ini menunjukkan bahwa guru mampu mengelola pembelajaran dengan baik serta guru mampu menciptakan suasana kelas yang kondusif dan mampu menarik perhatian siswa dalam melakukan eksperimen yang cukup menarik. Menurut Doymus dan Simsek (2009), pembelajaran GI sangat cocok untuk pembelajaran sains yang bertujuan untuk melibatkan siswa dalam penyelidikan ilmiah dan mendorong siswa untuk berkontribusi pada pembelajaran di dalam kelas.

Aktivitas siswa yang diamati pada setiap Rencana Pelaksanaan Pembelajaran terdiri dari memperhatikan penjelasan guru, menjawab pertanyaan yang diberikan guru, bergabung dengan kelompok, mengambil lotre untuk memilih topik, melakukan pembelajaran dalam kelompok, melakukan eksperimen, mengumpulan data, menganalisis data, diskusi dalam kelompok, mempersiapkan laporan akhir, mempresentasikan hasil laporan akhir, melakukan umpan balik, membuat kesimpulan, mengerjakan soal latihan, dan perilaku tidak relevan, dimana reliabilitas rata-rata pengamatan aktivitas siswa pada replikasi I, II, dan III adalah 92,21\%, 92,48\%, dan 92,28\%.

Hasil pengamatan aktivitas siswa yang diperoleh menunjukkan bahwa siswa berperan aktif dalam pembelajaran dengan menggunakan model group investigation dengan advance organizer. Hal ini didukung oleh pendapat Wahyuningsih, dkk (2012), siswa dituntut aktif dalam pembelajaran group investigasi dengan bekerjasama dengan kelompoknya untuk melakukan investigasi kelompok sebagai usaha dalam memecahkan masalah.

Ketuntasan hasil belajar siswa dinilai dari hasil belajar siswa yang didapat dari nilai pretest dan posttest yang dilakukan sebelum dan sesudah KBM. Hasil belajar siswa ditinjau dari ketuntasan hasil belajar terhadap pembelajaran model group investigation dengan advance organizer yang telah dilakukan. Ketuntasan hasil belajar meliputi: ketuntasan indikator, ketuntasan individual dan klasikal. Ketuntasan hasil belajar siswa dapat dilihat pada Gambar 1 dibawah ini. 
Gambar 1. Ketuntasan Indikator Produk dan Proses

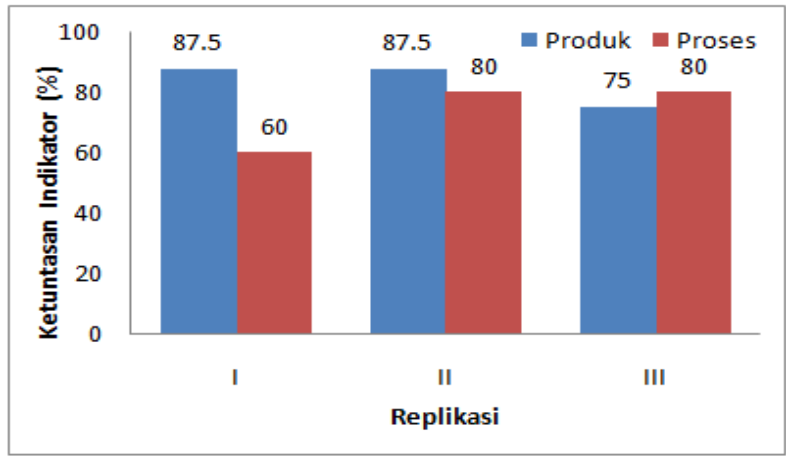

Ketuntasan indikator produk pada replikasi I, II, dan III sebesar 87,5\%, 87,5\%, dan $75 \%$, dan ketuntasan indikator proses (keterampilan pemecahan masalah) pada replikasi I, II, dan III sebesar $60 \%, 80 \%$, dan $80 \%$. Hasil analisis ketuntasan indikator tersebut sesuai dengan ketuntasan belajar setiap indikator yang telah ditetapkan dalam suatu kompetensi dasar berkisar antara 0-100\%. Kriteria ideal ketuntasan untuk masing-masing indikator 75\% (BSNP 2006).

Hasil analisis ketuntasan individual dan klasikal produk replikasi I, II, dan III pada Gambar 2 dan Gambar 3 menunjukkan bahwa nilai yang diperoleh setiap individu sebelum pembelajaran di bawah KKM (65), sehingga secara individual tidak ada yang tuntas. Setelah dilakukan pembelajaran model group investigation dengan advance organizer nilai yang diperoleh 72 siswa rata-rata di atas 65 (3 siswa yang mendapat nilai dibawah 65), sehingga ketuntasan hasil belajar produk secara klasikal dapat dikatakan tercapai (96\%). Hasil analisis nilai gain menunjukkan bahwa rata-rata nilai gain pada replikasi I, II, dan III adalah 0,73 berkategori tinggi, 0,76 berkategori tinggi, dan 0,69 berkategori sedang. Penentuan nilai gain ini sesuai dengan (Hake, 1998), jika nilai yang dihasilkan berada pada rentang 0,7 $>\mathrm{g} \geq 0,3$ maka $\mathrm{N}$-gain termasuk kategori sedang dan jika $\mathrm{g} \geq 0,7 \mathrm{~N}$-gain termasuk kategori tinggi. Hal ini menunjukkan bahwa siswa mengalami peningkatan pemahaman atau penguasaan konsep yang baik setelah dilakukan pembelajaran model group investigation dengan advance organizer.

Gambar 2. Ketuntasan Individu Produk dan Proses

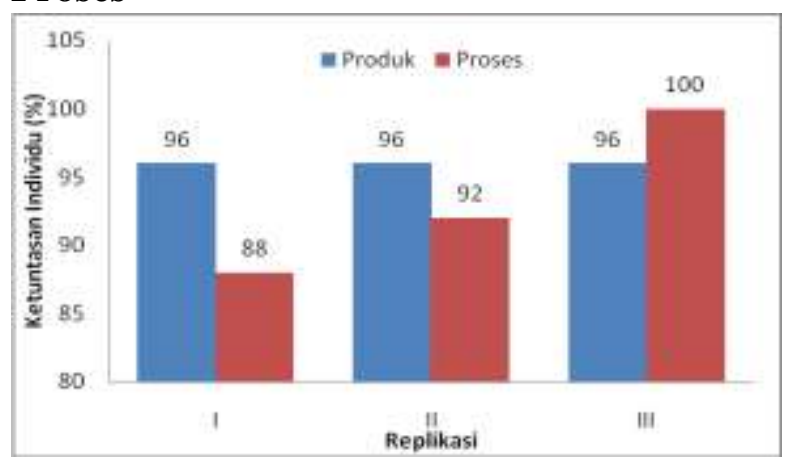

Hasil analisis ketuntasan individual dan klasikal proses replikasi I, II, dan III pada Gambar 2 dan Gambar 3 menunjukkan bahwa hasil pretest yang diperoleh siswa rata-rata di bawah 65, sehingga secara individual belum ada yang tuntas (0\%). Setelah dilaksanakan pembelajaran model group investigation dengan advance organizer, hasil posttest pada replikasi I menunjukkan bahwa nilai yang diperoleh 22 siswa yang memperoleh nilai ratarata $\geq 65$, sehingga ketuntasan hasil belajar proses (keterampilan pemecahan masalah) secara klasikal dapat dikatakan tercapai sebesar 88\%. Hasil posttest pada replikasi II menunjukkan bahwa nilai yang diperoleh 23 siswa yang memperoleh nilai rata-rata $\geq 65$, sehingga ketuntasan hasil belajar proses (keterampilan pemecahan masalah) secara klasikal dapat dikatakan tercapai sebesar $92 \%$. Sedangkan hasil posttest pada replikasi III menunjukkan bahwa semua siswa memperoleh nilai rata-rata $\geq 65$, sehingga ketuntasan hasil belajar proses (keterampilan pemecahan masalah) secara klasikal dapat dikatakan tercapai sebesar $100 \%$. Hal ini sesuai dengan pendapat Anggraini, dkk (2010), bahwa penerapan model investigasi kelompok akan meningkatkan kemampuan pemecahan masalah siswa.

Hasil analisis nilai gain pada replikasi I, II, dan III yang menunjukkan bahwa rata-rata nilai gain adalah 0,$62 ; 0,67$; dan 0,69 yang berkategori sedang. Hal ini menunjukkan 
bahwa siswa mengalami peningkatan pemahaman atau penguasaan konsep yang cukup baik setelah dilakukan pembelajaran model group investigation dengan advance organizer. Dari hasil analisis ketuntasan indikator, indikator yang tidak tuntas memiliki nilai gain yang baik (kategori sedang), karena skor antara pretest dan posttest memiliki perbedaan yang tinggi. Nilai gain yang baik ini memberikan efek yang bagus dalam pembelajaran.

Gambar 3. Ketuntasan Klasikal Hasil Belajar

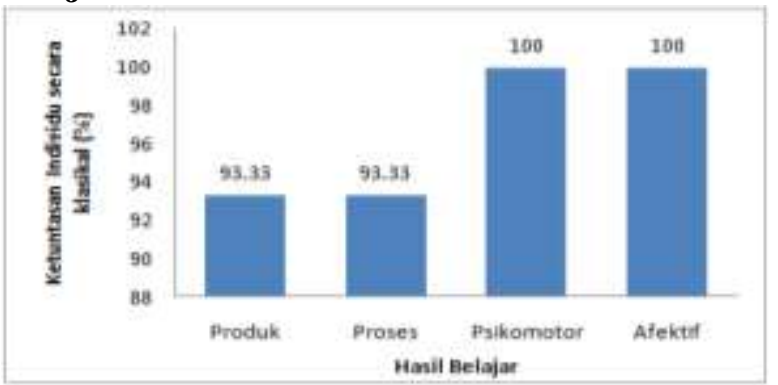

Hasil analisis ketuntasan individual dan klasikal psikomotor replikasi I, II, dan III pada Gambar 3 dan Gambar 4 menunjukkan bahwa hasil pretest yang diperoleh siswa rata-rata di bawah 65, sehingga secara individual belum ada yang tuntas $(0 \%)$. Setelah dilaksanakan pembelajaran model group investigation dengan advance organizer, hasil posttest menunjukkan bahwa nilai yang diperoleh semua siswa rata-rata di atas 65, sehingga ketuntasan hasil belajar psikomotor secara klasikal dapat dikatakan tercapai sebesar $100 \%$. Hal ini didukung oleh pendapat Risnawati, dkk (2012), yang menyatakan bahwa penerapan Group Investigation dapat mengembangkan karakter dan meningkatkan hasil belajar kognitif serta psikomotorik siswa.

Gambar 4. Ketuntasan Individu Psikomotor dan Afektif

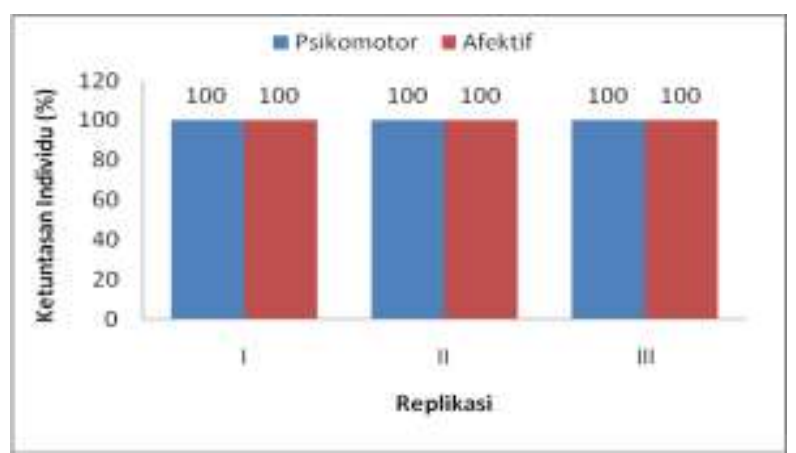

Hasil analisis ketuntasan individual dan klasikal afektif replikasi I, II, dan III pada Gambar 3 dan Gambar 4 menunjukkan bahwa menunjukkan bahwa nilai yang diperoleh semua siswa rata-rata di atas 65, sehingga ketuntasan hasil belajar afektif secara klasikal dapat dikatakan tercapai sebesar $100 \%$.

Siswa memberikan respon positif terhadap pembelajaran model group investigation dengan advance organizer yang telah dilaksanakan dengan kategori sangat baik. Hal ini menunjukkan bahwa perangkat pembelajaran yang dikembangkan dapat membantu guru meningkatkan hasil belajar dan keterampilan pemecahan masalah.

Kendala lapangan yang ditemui selama proses pembelajaran adalah pembelajaran model group investigation dengan advance organizer merupakan hal baru bagi siswa sehingga guru perlu memberikan informasi terlebih dahulu kepada siswa tentang pembelajaran model group investigation dengan advance organizer.

\section{PENUTUP}

\section{Kesimpulan}

Berdasarkan hasil dan pembahasan dapat disimpulkan bahwa perangkat pembelajaran model group investigation dengan advance organizer yang dikembangkan layak digunakan untuk meningkatkan hasil belajar dan keterampilan pemecahan masalah pada siswa SMPN 1 Tanjungbumi.

\section{Saran}

Berdasarkan pada hasil penelitian yang telah dilakukan, disarankan: 1) Penggunaan perangkat pembelajaran model group investigation dengan advance organizer yang dikembangkan ini dalam pembelajaran di kelas memerlukan waktu yang lebih lama untuk mempersiapkannya, sehingga perlu adanya persiapan yang matang, dan 2) Pengelolaan kelas harus dilakukan sebaik mungkin agar siswa dapat belajar dengan nyaman dan situasi kelas tidak ramai. 
DAFTAR PUSTAKA

[1] Anggraini, L., Siroj, R., \& Putri, R. I. I. 2010. "Penerapan Model Pembelajaran Investigasi Kelompok untuk Meningkatkan Kemampuan Pemecahan Masalah Matematika Siswa Kelas VIII-4 SMP NEGERI 27 PALEMBANG". Jurnal Pendidikan Matematika, Volume 4. No. 1.

[2] Borich, G. D. 1994. Observation Skills for Effective Teaching. New York: Macmillan Publishing Company.

[3] BSNP. 2006. Naskah Akademik Instrumen Penilaian Buku Teks Pelajaran Pendidikan Dasar Dan Menengah. Jakarta: BSNP.

[4] Dewi, R. P., Iswari, R. S., \& Susanti. 2012. "Penerapan Model Group Investigation terhadap Hasil Belajar Materi Bahan Kimia di SMP”. USEJ 1 (2). ISSN 2252-6617.

[5] Doymus, K \& Simsek, U. 2009. "Effects of Two Cooperative Learning Strategies on Teaching and Learning Topics of Thermochemistry". The World Applied Sciences Journal 7(1): 33-42.

[6] Efendi, R. 2010. Kemampuan Fisika Siswa Indonesia dalam TIMSS (Trend of International on Mathematics and Science Study). Prosiding Seminar Nasional Fisika 2010. ISBN: 978-979-98010-6-7.

[7] Hake, R. 1998. "Interactive-engagement methods in introductory mechanics courses". Journal of Physics Educational Research. 66, 64-74.

[8] Karli, H \& Sriyuliariatiningsih. 2004. Implementasi Kurikulum Berbasis Kompetensi, Model-Model Pembelajaran. Bandung: Bina Media Informasi.

[9] Mcklar. 2008. Penerapan Pembelajaran Kooperatif Model Group Investigation untuk Meningkatkan Motivasi dan Hasil Belajar Siswa pada Mata Diklat. http://akhmadsudrajat.wordpress.com/200 9/06/20/ pembelajaran-kooperatif-metodegroup investigation/\#more-623. Diakses tanggal 26 Desember 2012.

[10] Provasnik,S., Kastberg, D., Ferraro, D., Lemanski,N., Roey S., \& Jenkins F. 2012. Highlights from TIMSS 2011 mathematics and science achievement of U.S. fourthand eighth-grade students in an International context. http://www.cde.state.co.us/assessment/doc uments/newsreleases/2012/HighlightsFro mTIMSS2011Math AndScience-IESUSDOE.pdf. Diakses tanggal 30 Juli 2013.

[11] Risnawati, Yulianti, D., \& Dwijananti, P. 2012. "Penerapan Group Investigation pada Pembelajaran Sains untuk Mengembangkan Karakter Siswa SMP Kelas VIII". UPEJ 1 (1). ISSN NO 22526935.

[12] Slavin, R.E. 1995. Cooperative Learning; Theory, Research, and Practice. Second Edition. Boston: Allymand Bacon Publisher.

[13] Suhendri, D \& Sahyar. 2012. "Efek Model Pembelajaran Kooperatif Tipe Group Investigation terhadap Hasil Belajar Siswa pada Materi POkok Kalor Kelas VII Semester 1 SMP IT-FITYAN MEDAN". Volume: 1 (1). ISSN 2301-7651.

[14]Trisdiono \& Muda. 2013. Strategi Pembelajaran Abad 21. http://lpmpjogja.org/index.php/artikeldank aryailmiah/harli-trisdiono-mm/26-strategipembelajaran-abad-21. Diaskes tanggal 2 Juni 2013.

[15]TSOI, M. F., GOH, N. K, \& CHIA, L. S. 2004. "Using group investigation for chemistry in teacher education". Volume 5, Issue 1, Article 6, p.1.

[16] Wahyuningsih, I.,Sarwi, \& Sugianto. 2012."Penerapan model kooperatif group investigation berbasis eksperimen inkuiri terbimbing untuk meningkatkan aktivitas belajar". Journal 1 (1). ISSN NO 22576935. 